\title{
Model Of Policy Implementation Corporate Social Responsibility ( Csr) For Empowering Small-Medium Micro Businesses (Smmb)
}

\author{
${ }^{1}$ Dr. Hj. Mahmudah Enny W., Dra.,Ec.,M.Si , ${ }^{2}$ Drs. Heru Irianto, MS.i \\ ${ }^{3}$ Dr.Rr Herini Siti Aisyah, SH, MH , ${ }^{4}$ Budiono, SE., M.Ak., Ak.
}

\begin{abstract}
The purpose of the study was to find a model of the implementation of CSR programs in its role to empower SMMB. In this model independent institutions were established at certain government levels - from the levels of the district to the regency. At the district level a forum was formed to facilitate the implementation of CSR and the administrative operation was headed by the company staff. While at the regency a permanent secretariat for the team of CSR program facilitation was formed and the managerial staffs were the regency officials with their leading sector-BAPPEDA. It was highly expected that overlapping or social conflicts among the government, companies and people could be avoided through the establishment of independent institutions. Thus the vision and mission of each party can be achieved in a mutual symbiosis manner.
\end{abstract}

Keywords : CSR, Microeconomics.

\section{Introduction}

The Central Bureau of Statistics stated that the number of registered SMMB was 42.3 million or 99.90 $\%$ of the number of business units. The workers employed were as many as 79 million or $99.40 \%$ of the total workforce. The contribution of SMMB in the formation of GDP was $56.70 \%$, and the contribution of the foreign exchange was $\mathrm{Rp} 75.80$ trillion or $19.90 \%$ of the total value of exports . (Konsultan Sektor Riil \& UMKM Indonesia).

The data indicated that SMMB had an important role in Indonesia's economy and was potential to develop. After the issue of Act No. 40 the year 2007 which regulates the obligation of companies to program and implement the Corporate Social Responsibility (CSR), it is necessary to develop a model synergizing large companies, SMMB and governments to build the Indonesian economy.

SMMB empowerment through CSR was an appropriate concept of development since it was highly stressed and focused on "doing with the community" rather than "doing for the community". The approach of "doing with" stimulated the people to be active and dynamic, and they were able to identify kinds of need - real needs, felt needs and the expected needs; It resulted in the independence of SMMB. (http://mahmudisiwi.net/definis)

\section{Previous Studies}

\section{Review Of Literature}

CSR programs must be sustainable (Chairil N. Siregar, 2007 p.: 288). The assessment of the implementation of CSR is necessary and carried out by external parties (CSR Study Circle, 2007:6). The social responsibility towards the stakeholders of the company is the responsibility of both the government and the company as an institution getting the income from the nature and the environment (Ketut Budiartha, 2008:214). The implementation of CSR is viewed as a compulsory. CSR is not only a responsibility but also an obligation (Dessy Ariyati S, dkk 2008). In the external scope the implementation of CSR should be able to improve the social and economic aspects of the environment surrounding the company in particularly and the people in general. (THESIS, http://gudangmakalah. blogspot.com/2010/04/tesis).

The implementation of CSR should be conducted with more emphasis on the solid and synergic cooperation and other stakeholders, especially the local government. (Adlin Hafidza and N Norist , 2011:604). The results of the previous studies indicated that the implementation of CSR has not been effective due to several reasons. One of them was that CSR was interpreted in various ways by each company so that its implementation was not synergyic. Beside that the CSR evaluation was carried out by each company itself resulting in the dubious validity. There was a cocern from the Vendor related with tax incentives for the implementation of CSR programs. It was necessary to share the responsibility to synergize the running of the CSR programs more effectively and efficiently.

\section{Role of CSR in the Empowerment of SMMB}

Community Development is not a new thing along with the issue of Act No. 40 the year 2007 about corporate companies. At the moment many of these activities have been adopted by companies as their 
corporate social responsibility objectives with much broader scope in the activities. The funds allocated are higher. The social activities, however, are still oriented to short term programs like charity to help people in shortages. It should be deeply realized that CSR activities, as a form of corporate social solidarity, are useful not only for the people, but also for the image of the company. They can be used as a tool to build the brand image of the company. Through the right publication and cooperation with the people, the company will be widely known as good corporate citizenship. (http://informasi-seminar.com/aplikasi).

There are some causes of CSR failure in reducing some conflicts or tension between companies and people living nearby. First, the CSR programs are not implemented in accordance with the needs of the people, and secondly, the implementation of CSR programs is facing some weaknesses. (Pusat Studi Kawasan dan Pedesaan UGM 2010). To overcome these constraints, the local governments can actually facilitate the resources owned by the company through its CSR program aiming to develop entrepreneurship in the region. (Rissalwan, 2011:614)

\section{The Implementation of CSR Policy to Empower SMMB}

Some efforts to stimulate the ability and the toughness of SMMB are activities that cannot be separated from such kind of activities to cultivate the ability, toughness and overall the national security. (Jawa Post, July 16, 2001). Act No. 40 the year 2007 describes the social and environmental responsibilities of the companies. They have the responsibility towards the progress of the environment around the companies through the CSR programs. ( http://cpanel.petra.ac.id/ejournal/i )

Generally the concept of CSR states that the company's responsibility is not only to its owners or shareholders, but also to the relevant stakeholders and/or affected by the existence of the company. (http://ilmiahekonomi.blogspot.com/ 2011). CSR will be an inherent business strategy in the company to maintain or improve the competitiveness through product reputation and brand loyalty or corporate image. Thus It can create an ecosystem giving some benefits to all parties (true win win situation) (copyright @ timotheus_lesmana).

Empower people covers various sectors such as sectors of economic, social and others. In fact, not all companies perform its CSR obligations. Some question arise in a variety of negative indications. How should every company impelment its CSR programs? Is a special policy needed to regulate social responsibility undertaken by each company? (Parahyangan Catholic University Team : p. 3).

\section{Research Methods}

The main sources of information in this study were the companies that implement CSR programs, local governments, and UMK. Snow Bolling and entry points of the companies implementing CSR policies were applied to determine the resources of information. In-depth interview technique was conducted to obtain the data related with the activities of the organization, motivation, behavior and so on (Irianto, 2001). Then the results of the interviews was discussed with the technique of Focus Group Discussion (Bungin, 2001: 172 ).

\section{Basic Regulation of CSR Policy}

\section{Results and Discussion}

The rule of law that requires companies to implement CSR activities includes the Regulation of the Minister of the State-Owned Enterprises No.: 05/MBU/2007. It is stated thet the State-Owned Enterprises (SOEs) must implement the Progams of Partnership and Community Development in accordance with the Regulation of the Minister of State-Owned Enterprises No.: Per-05/MBU/2007 Article 1 (6) associated with the programs of partnerships and community development. For the companies managing the Natural Resources, it is highly required to implement social and environmental responsibilities set out in the corporate companies Act No.40 the year 2007. (1) The Companies conducting the business activities in the field and/or related to the natural resources are strongly required to implement Social and Environmental Responsibilities. (2) Social and Environmental Responsibilities as referred to paragraph (1) an obligation of the company to allocate some funds and calculate the cost in its budget and the implementation is carried out with regard to the appropriateness and reasonableness. (3) The Companies not carrying out the obligations referred to paragraph (1) are sanctioned in accordance with the regulations. (4) Further provisions on Social and Environmental Responsibilities are set by the government regulation. Act No. 25 the year 2007 on Investment, particularly Article 15 (b) states that each investor shall implement the corporate social responsibility. The companies managing oil and gas are bound by the Act No. 22 the year 2001 on Oil and Gas. Article 13, paragraph 3 regulates the obligations for the development of the surrounding community and honors and guarantees the rights of adat peoples. (Rahmatullah S.Sosm 2011: 99). CSR is the right program to develop the economy of both macro and micro levels. The stateowned enterprises are also public companies bound by 2 regulations regulating the publicly listed company and State-Owned Enterprises. The Minister Regulation No. 05/ MBU/2007 regulates the guidelines for 
implementation of the programs of partnership and community development and the sources of funds - the company 's net profit after tax up to $2 \%$.

\section{Role of CSR in the Development of SMMB}

It is expected that CSR program, directly and indirectly involving some parties such as government, suppliers, distributors, employees, communities, non-government organizations (NGO), local governments, consumers, can be conducted continuously as it is as one of the fundamental aspects in sustainability. Each program in CSR activities should be well-arranged for a certain period of time and implemented not only for the short term but also for the medium and long terms. Making and designing a series of activities must pay special attentions to environmental, social, and religious factors. For example, after some funds are granted as the capital for the people to manage, the company is supposed to give special trainings on how to run micro and small enterprises and to preserve the environment. After the business runs well, and gains a lot, the people should also be taught how to develop the business, so that the local resources can be totally absorbed. Sustainable and integrated patterns in the development can provide an alternative breakthrough to empower the communities to address the social and environmental issues which are increasingly getting more and more complicated in the last decade. The empowerment of SMMB through CSR can develop the macro and microeconomiy resulting in the balance of economy which should be well maintained. It will make the economy of the country will grow and develop well.

\section{Model Design}

Independent institutions from the levels of district to regency are established. A forum at the level of district is formed to facilitate the implementation of CSR and the running is headed by the staff of the company. While at the regency level, a permanent secretariat team is formed to facilitate CSR programs and the managing boards are the regency officials with BAPPEDA as the leading sector. The establishment of the independent institution is expected to avoid the overlapping or social conflicts between the government, companies and society. Thus the vision and mission of each party can be achieved in a mutual symbiosis.

\section{MODEL DESIGN OF POLICY IMPLEMENTATION$$
\text { CORPORATE SOCIAL RESPONSIBILITY (CSR) }
$$

TO EMPOWER SMALL-MEDIUM MICRO BUSINESSES (SMMB)

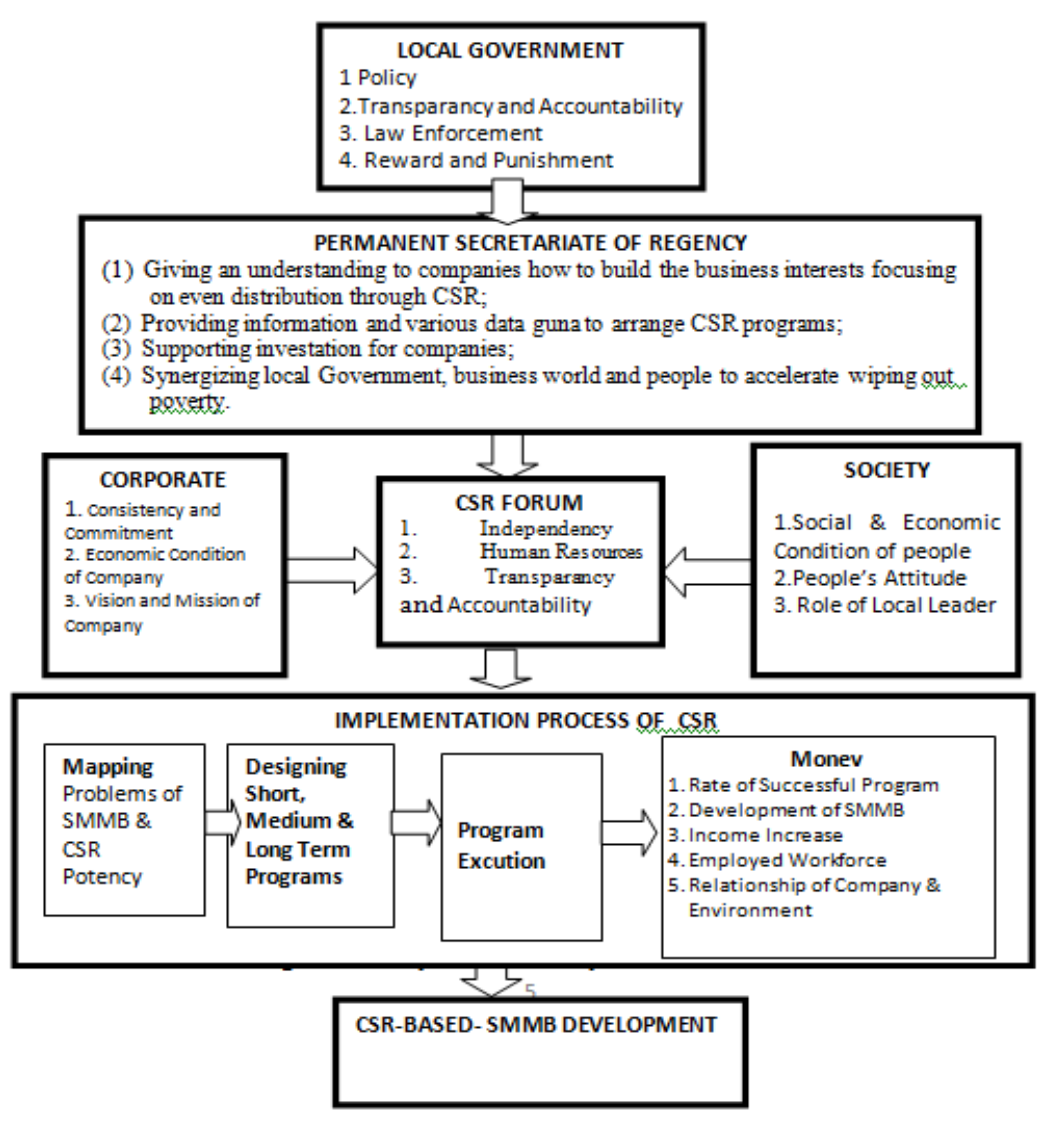




\section{Conclusion}

1. Government supports with the regulations and the establishment of independent institutions are crucial in the implementation of CSR policy. They are very important to avoid conflicts of interest. Through CSR there is a great possibility to synergize government, companies and communities resulting in a mutual symbiosis leading to the better and stronger economy of the country.

2. Based on the implementation of SCR, the companies are classified into three types. The first ones are big private companies. The companies of this type implement and manage its CSR programs professionally and consistently. They build a special institution or agency to run the CSR programs. The second ones are state-owned enterprises. In the implementation of CSR, they are subject to some ministerial regulations. They play important roles and are managed professionally so that they can provide soft loans to SMMB, foster good managements of finance, human resources and marketing. The third ones are a type of companies which do not belong to the first and second types. The financial condition of this type of company is different from of the previous ones. big companies or state-owned enterprises. The firms of this category implement the CSR temporarily and directed to the people living around. The implementation of CSR has not been well conceptualized so that the role of independent institutions is indispensable.

3. The establishment of independent institutions are intended to have a strategic step to synergize companies, governments and communities in playing their roles by recognizing the clear boundaries of their fields so that the sustainability of CSR programs can be guaranteed.

\section{Recommendations}

1. To enhance the role of CSR in SMMB, it is necessary to empower the local government to play their active roles by issuing the regulations related with the technical matters in the implementation of CSR program. The establishment of an independent institution accelerating the economic growth through the development of SMMB is based on partnerships.

2. For large enterprises and the state-owned enterprises, the implementation of CSR programs should be integrated with the central and local government program and in line with the vision and mission of the company and the government.

3. The establishment of an independent agency that handles the implementation of CSR programs in many areas should be used as a Prototype and they can be developed in other areas and even in the national levell so that the CSR is not just a slogan. but it has its significant role in Indonesian development. It is highly relevant to the philosophy of the Indonesian nation, namely Pancasila. If this model can be applied continouosly and consistently across Indonesia, the economic gap can be reduced and the prosperous society in the long run can be realized .

\section{References}

[1]. Anonim, Pusat Studi Pedesaaan dan Kawasan UGM, 2010, anda mengalami masalah dengan corporate social responsibility

[2]. Anonim, Corporate Social Responsibility: Konsep, Regulasi dan Implementasi Tim Universitas Katolik Parahyangan

[3]. Anonim, Harian Analisa, Opini - Selasa, 29 Nov 2011

[4]. Anonim, Konsultan Sektor Riil \& UMKM Indonesia http://usaha-umkm.blog.com/tag/pemberdayaan-umkm/

[5]. Anonim, Karakteristik CSR di Perusahaan Besar laboratorium pengembangan ekonomi pembangunan fakultas ekonomi dan bisnis unair, pemetaan perusahaan besar dan menengah kabupaten sidoarjo" 2012

[6]. Budiartha, ketut, 2008, Cara pandang undang-undang ri no. 40 tahun 2007 dan undangundang ri no. 17 tahun 2000 terhadap corporate social responsibility (csr) buletin studi ekonomi volume 13 nomor 2 tahun 2008 jurusan akuntansi fakultas ekonomi, universitas udayana, denpasar

[7]. Bungin, Burhan, 2001, Metodologi Penelitian Sosial, Airlangga University Press,

[8]. Irianto, Heru, Edit Bungin, 2001, Metode Penelitian Kulaitatif, PT RajaGrafindo Persada, Jakarta

[9]. Lingkar Studi CSR, 2007, www.csrindonesia.com, e-mail: office@csrindonesia.com) 16 Juli 2007 Dikutip 20 Pebruari 2012

[10]. Lubis, Rissalwan Habdy, 2011, Transformasi Tanggung Jawab Sosial Perusahaan kepada Kewirausahaan Sosial, Manajemen Usahawan Indonesia Vol.40 No.6 Nopember-Desember 2011

[11]. Norist, Adlin Hafidza dan N 2011, Eavluasi Aktivitas dan Pelaporan CSR Studi Kasus PT X, Manajemen Usahawan Indonesia Vol.40 No.6 Nopember-Desember 2011

[12]. Perda Propinsi Jawa Timur Nomor 4 tahun 2011 Tentang Tanggung Jawab Sosial Perusahaan (TSP).

[13]. Rahmatullah S.Sosm 2011 : 99 CSR DAN KEPENTINGAN PEMERINTAH DAERAH Proceeding Simposium Nasional Otonomi Daerah 2011 ISBN: 978-602-96848-2-7 LAB-ANE FISIP Untirta

[14]. S, Dessy Ariyati, Risky Fitria, Sheridan Olenka, Diane Pitaloka, Naresthi Ayu Milkoma, Tindakan dari Corporate Social Responsibility yang Dilakukan Oleh Perusahaan Indosat (http://bisnisgroup.wordpress. com/2008/10/10/

[15]. Siregar chairil., 2007, Analisis sosiologis terhadap implementasi corporate social responsibility pada masyarakat indonesia jurnal sosioteknologi edisi 12 tahun 6, desember 2007

[16]. Sukarmi,2010, http://www.djpp.depkumham.go.id/hukum-bisnis/84-tanggung-jawab-sosial-perusahaan-corporate-socialresponsibility-dan-iklim-penanaman-modal.html Dikutip 20 Pebruari 2012

[17]. http://businessenvironment.wordpress.com/2007/03/01/program-corporate-social-responsibility-yang-berkelanjutan/ Dikutip 20 Pebruari 2012

[18]. http://kajian-csr.blogspot.com/2011/01/tujuan-csr.html

[19]. http://businessenvironment.wordpress.com/2007/03/01/program-corporate-social-responsibility-yang-berkelanjutan/ Dikutip 20 Pebruari 2012 
Model Of Policy Implementation Corporate Social Responsibility ( Csr ) For Empowering Small-

[20]. http://cpanel.petra.ac.id/ejournal/index.php/dkv/article/viewArticle/17049

[21]. http:/gudangmakalah.blogspot.com/2010/04/tesis-implementasi-corporate-social.htm tesis implementasi corporate social responsibility (csr) terhadap masyarakat di lingkungan ptpn x (prodi : ilmu hukum

[22]. http://ilmiahekonomi.blogspot.com/2011/02/faktor-faktor-yang-empengaruhi.html

[23]. http://informasi-seminar.com/aplikasi-implementasi-csr-secara-efektif-2/)

[24]. http://kajian-csr.blogspot.com/2011/01/tujuan-csr.html)

[25]. http://kelanakota.suarasurabaya.net/?id=189ecb4504a54d97b6c3903a4669c504201191359 dikutip tanggal 20 Pebruari 2012

[26]. http://mahmudisiwi.net/definisi-community-development Community Development dikutip 20 Pebruari 2012

[27]. http://www.scribd.com/doc/51106562/1UKM Selalu Terbentur Birokrasi Jawa Pos, 16 Juli 2001.

[28]. SURYA Online 28/2/2013

[29]. Suara Indrapura, :Selasa; 26/02, DPRD Jatim Online 